\title{
Recycling pulp mill sludge to volcanic soil: a column leaching study
}

\author{
F. Gallardo ${ }^{1,3^{*}}$, G. Briceño ${ }^{1,3}$, M.J. Flores ${ }^{3}$, M.C. Diez ${ }^{2,3}$
}

${ }^{1}$ Chemical Science and Natural Resources Department, La Frontera University, Avenida Francisco Salazar 01145, P.O Box 54-D, Temuco, Chile. ${ }^{2}$ Chemical Engineering Department, La Frontera University, Avenida Francisco Salazar 01145, P.O Box 54-D, Teтuco, Chile. ${ }^{3}$ Scientific and Technological Bioresource Nucleus, La Frontera University, Avenida Francisco Salazar 01145, P.O Box 54-D, Temuco, Chile. *Corresponding author:felipe.gallardo@ufrontera.cl

\begin{abstract}
A leaching experiment was conducted to determine the influence of four successive applications of pulp mill sludge on some parameters of an Andisol. Undisturbed soil columns were treated with pulp mill sludge (0 to $\left.30 \mathrm{Mg} \mathrm{ha}^{-1}\right)$ every three months during one year with a hydraulic regime of $1200 \mathrm{~mm}$ per year. Leachates of each treatment were analyzed periodically and, at the end of the period, columns were fractionated at three depths $(0-20,20-40$ and 40-60 $\mathrm{cm})$ and soil chemical parameters were analyzed. Sludge added successively to Andisol increased the nitrate concentration in leachates. After the fourth application of $30 \mathrm{Mg} \mathrm{ha}^{-1}$ sludge, nitrate leaching was about 1.7 times higher than in the control column, however, this level is still lower than the limit under Chilean regulations. Low ammonium concentrations were observed in leachates as a result of nitrification processes and retention by clay and organic matter in the Andisol. In fractionated soil columns, $\mathrm{pH}$, organic matter, total nitrogen and phosphorus increased as the sludge rate increased, with the highest values found in the upper part of the columns. The concentration of nitrate and ammonium in soil columns followed an inverse pattern: while ammonium concentration was the highest at 0 to $20 \mathrm{~cm}$, nitrate concentration was the lowest in that fraction; sludge addition caused a linear increase in ammonium and nitrate content at the three depths analyzed.
\end{abstract}

Keywords: Andisol, leaching, pulp mill sludge, repeated application 


\section{Introduction}

The pulp and paper industry has become one of the most important industries in the world. However, this productive activity is directly associated with environmental problem related with wastewater generation, solid wastes including sludge generating from wastewater treatment plants and air emissions (Hossain and Ismail, 2015). Nowadays, application of industrial residues to soil is increasingly being investigated as an alternative option to chemical fertilizers and as a soil amendment. It may also reduce treatment and disposal costs, enhance soil fertility, improve growth conditions for crops and increase crop yields (Yuan et al., 2011; Gallardo et al., 2012; Masud et al., 2014).

Chile is the second largest producer of cellulose in Latin America, with current production of 4.7 million tons per year. The biological wastewater treatment plants of the pulp and paper industry produce large quantities of sludge (0.2-1.2 $\mathrm{kg}$ dry matter $(\mathrm{DM}) / \mathrm{kg}$ biological oxygen demand (BOD) removed), that require disposal. At present, the conventional uses of sludge include industrial use, landfill, combustion and composting for application to farmland (Sánchez et al., 2004). This sludge generally contains organic substances, such as cellulose, lignin and microorganisms; and inorganic substances, such as nitrogen $(\mathrm{N})$, phosphorus $(\mathrm{P})$, potassium $(\mathrm{K})$, silt, clay, calcium carbonates and metals. Pulp mill sludge improves the physical, chemical and biological properties of soils; its use increases soil $\mathrm{pH}$ and organic matter (OM) content, improves soil structure, and consequently increases soil productivity (Aravena et al., 2007; Nunes et al., 2008; Gallardo et al., 2010). In addition, it facilitates nutrient transport, increases water-holding capacity and serves as a partial replacement for the most expensive chemical fertilizers. Sludge also may improve the cation exchange capacity and microbial activity of soils (Nunes et al., 2008; Gallardo et al., 2012).

Several researchers have demonstrated the beneficial effect of pulp mill sludge as a soil amendment. However, little information has been published on the application of pulp mill sludge to volcanic soil, and how soil and groundwater could be affected by repeated applications. The feasibility of applying sewage sludge to soils increases with both the amount of sludge applied and the number of reapplications (Egiarte et al., 2005). According to Egiarte et al. (2005), the ability of soil to assimilate $\mathrm{N}$, the cumulative effect of nutrients and contaminants on the soil, the changes in the bioavailability of pollutants with time and the history of previous sludge applications must all be taken into account to ensure that repeated sludge applications are properly managed. On the other hand, Tamir et al. (2013) demonstrated that the addition of organic residues to enhance soil fertility results in $\mathrm{N}$ mineralization and transformation, which may have important effects on chemical processes in the amended soils.

In Chile, there are approximately 3.1 million ha of soil derived from volcanic ash (Andisol and Ultisol). Their main characteristics are acid $\mathrm{pH}$, high extractable aluminum (Al) and high $\mathrm{P}$ fixation, which increases when the $\mathrm{pH}$ decreases (Mora et al., 2005), affecting soil productivity. In acidic soils moreover, soluble Fe, Al, and Mn are usually present in higher concentrations, and $\mathrm{P}$ reacts with these ions to produce insoluble compounds unavailable to plants (Gallardo et al., 1999). Moreover P availability decreases due to $\mathrm{P}$ fixation by hydrous oxides of $\mathrm{Fe}$ and $\mathrm{Al}$ and also by adsorption. The use of pulp mill sludge may improve the content of available P (Gallardo et al., 2012), by increasing soil $\mathrm{pH}$ and thus reducing $\mathrm{Al}$ saturation. According to Masud et al. (2014), aluminum toxicity 
and infertility are the main factors limiting plant growth and development in acidic soils.

Pulp mill sludge has a high $\mathrm{N}$ content that may be transformed into plant-available forms, either as ammonium $\left(\mathrm{NH}_{4}^{+}-\mathrm{N}\right)$ or nitrate $\left(\mathrm{NO}_{3}^{-}-\mathrm{N}\right)$ (Ribeiro et al., 2010). In general, $\mathrm{NH}_{4}^{+}-\mathrm{N}$ is tightly bound by the negatively charged surfaces of clay complexes and $\mathrm{OM}$, and thus immobilized. By contrast, $\mathrm{NO}_{3}^{-}$ -N with a negative charge can readily be lost from negatively charged soils, resulting in environmental contamination (Gilmour et al., 2003; Ribeiro et al., 2010). Large amounts of $\mathrm{N}$ applied in paper mill sludge could potentially cause $\mathrm{NO}_{3}^{-}-\mathrm{N}$ leaching (Feldkinchner et al., 2003). Therefore, in order to protect soil and humans from pollution, the recommended sludge dose should set so as to avoid excessive leaching of $\mathrm{NO}_{3}^{-}-\mathrm{N}$ into groundwater and excessive loading of heavy metals and organic pollutants in soils (Egiarte et al., 2005). The environmental risks of pulp mill sludge may be estimated by monitoring leaching of certain elements that can contaminate groundwater. The aim of this work was therefore to evaluate the nutrient supply to soil, potential for $\mathrm{NO}_{3}^{-}-\mathrm{N}$ and $\mathrm{NH}_{4}^{+}$-N leaching, and $\mathrm{P}$ availability with successive applications of pulp mill sludge in increasing doses to an Andisol.

\section{Materials and Methods}

\subsection{Soil and sludge}

The sludge used in this assay was obtained from a bleached Kraft pulp mill wastewater treatment plant (aerated pound) and, was collected from a landfill one year after disposal. Under this condition, sludge becomes stable naturally and complies with the requirements established in Chilean Standard NCh 2880 (INN, 2004). The soil used for this study was an Andisol derived from volcanic ash, belonging to the Freire Series, located in Southern Chile ( $38^{\circ} 42^{\prime} \mathrm{S}$, $73^{\circ} 35^{\prime} \mathrm{W}$ ) at Maquehue Experimental Station of Universidad de la Frontera. The soil sample for the characterization was taken from $0-20 \mathrm{~cm}$ depth, air dried at room temperature, sieved through a $2 \mathrm{~mm}$ mesh and stored in plastic bags under refrigeration $\left(4^{\circ} \mathrm{C}\right)$.

\subsection{Soil column assay}

The leaching assay was carried out using undisturbed soil. PVC cylinders (diameter $14 \mathrm{~cm}$, height $60 \mathrm{~cm}$ ) were buried in the soil, using a hydraulic device which pushed the cylinder down by small increments to minimize disturbance to the soil structure inside. Once the cylinders reached the desired depth (60 $\mathrm{cm}$ ), they were lifted out of the collection site and taken to the laboratory without disturbing the soil. A plastic disc was used to close the lower end of each cylinder and an L-shaped tube (1/4 inch diameter) was placed in the center of the plastic disc to receive the leachates. The columns were installed in the laboratory under controlled temperature conditions $\left(20 \pm 2^{\circ} \mathrm{C}\right)$. The sludge was applied to the upper part of the columns, in the range 0 to $30 \mathrm{Mg} \mathrm{ha}^{-1}$ (DW sludge equivalent), and gently mixed with the first $5 \mathrm{~cm}$ of soil. Re-applications were made every three months until one year of treatment. There were three replicates per treatment and columns without sludge addition were used as controls. Distilled water was added daily to each column, simulating a rainfall regime of $1200 \mathrm{~mm}$ per year. Leachates were collected every week and stored under frozen conditions (12 subsamples per application). After the last subsample was collected, the frozen subsamples were defrosted and homogenized for the analysis of $\mathrm{N}$ (in the form of $\mathrm{NO}_{3}^{-}-\mathrm{N}$ and $\mathrm{NH}_{4}^{+}-\mathrm{N}$ ), $\mathrm{pH}$ and P. At the end of the experiment, the soil was extracted from the cylinders and was fractionated in depths from $0-20,20-40$ and 
40-60 $\mathrm{cm}$. These samples were air dried and sieved through a $2 \mathrm{~mm}$ sieve and analyzed to determine $\mathrm{pH}$, $\mathrm{OM}$, available $\mathrm{P}$, total $\mathrm{N}, \mathrm{NO}_{3}^{-}-\mathrm{N}$ and $\mathrm{NH}_{4}^{+}-\mathrm{N}$.

\subsection{Analyses of soil, sludge and leachates}

Soil samples and sludge were analyzed according to Sadzawka et al. (2004). Organic carbon (OC) content was determined by the dichromate oxidation method and colorimetric determination of the reduced chromate $\left(\mathrm{Cr}^{+3}\right)$; OM content was obtained by multiplying the OC content by the factor 1.724 ; $\mathrm{pH}$ was measured in 1:2.5 (w/v) soil/water mixture; total $\mathrm{N}$ content by the Kjeldahl method; mineral $\mathrm{N}\left(\mathrm{NO}_{3}{ }^{-} \mathrm{N}\right.$ and $\left.\mathrm{NH}_{4}^{+}-\mathrm{N}\right)$ by extraction with $\mathrm{KCl}$ $2 \mathrm{M}$ and titration with $\mathrm{HCl}$ and specific electrode respectively; and available $\mathrm{P}$ by extraction with sodium bicarbonate $(0.5 \mathrm{M}, \mathrm{pH} 8.5)$ and determined colorimetrically with the molybdate-ascorbic acid method. Available macro and microelements were determined by atomic absorption spectrophotometry (Shimadzu GBC SensAA). Ca, Mg, K, and Na were quantified after extraction with ammonium acetate $1 \mathrm{M}, \mathrm{pH}$ 7.0; $\mathrm{Fe}, \mathrm{Mn}, \mathrm{Cu}$ and $\mathrm{Zn}$ were quantified after extraction with a solution composed of DTPA (diethylenetriaminepentacetic acid), calcium chloride and TEA (triethanolamine) buffered at $7.3 \mathrm{pH}$; and $\mathrm{Al}$ was quantified after extraction with $\mathrm{KCl} 1 \mathrm{M}$ (1:10 soil/ solution ratio) by shaking for $24 \mathrm{~h}$. All the analyses were done in triplicate. In the column leachates, $\mathrm{pH}$ was measured by potentiometry; $\mathrm{NO}_{3}^{-}-\mathrm{N}^{-}$and $\mathrm{NH}_{4}^{+}-\mathrm{N}$ by specific electrode after Kjeldahl distillation, and $\mathrm{P}$ was determined by the colorimetric method.

\subsection{Statistical analysis}

All the experiments were carried out in triplicate. The data were statistically analyzed by one-way analysis of variance (ANOVA), where statistical differences were observed, and means were separated using Tukey's minimum significant difference test $(p<0.05)$.

\section{Results and Discussion}

\subsection{Chemical characteristics of soil and sludge}

The principal chemical characteristics of the soil and sludge used in this study are shown in Table 1. This soil presented typical characteristics of Andisols, with moderate acidity ( $\mathrm{pH} 5.5$ ) resulting in low Al saturation probably due to changes in the equilibrium of neutral species of $\mathrm{Al}\left(\mathrm{Al}(\mathrm{OH})_{3}\right)$ as $\mathrm{pH}$ increased. The soil presents basal levels of $\mathrm{N}, \mathrm{P}$ and $\mathrm{K}$ for crop production, therefore, no supplements of these elements were considered in this study. The sludge presented a higher content of OM (68\%), macronutrients $(\mathrm{N}, \mathrm{P}$, $\mathrm{K}, \mathrm{Ca}$ and $\mathrm{Mg}$ ) and micronutrients ( $\mathrm{Mn}, \mathrm{Cu}$ and $\mathrm{Zn}$ ) than the soil. Conversely, the contents of $\mathrm{Fe}$ and $\mathrm{Al}$ were lower than in the soil. Considering the properties of the sludge, it was expected that its addition would help to improve soil characteristics and hence fertility. The application of recycled paper mill sludge with similar values of $\mathrm{pH}$ and $\mathrm{OM}$ that the sludge used in this study has been associated with substantial benefit such as increases the $\mathrm{OM}$ and other essential nutrients, and soils $\mathrm{pH}$ neutralization specially in acid soils (Abdullah et al., 2015). Previous studies done in our research group have shown positive effects on the physical, chemical and biological properties of several Andisols amended with pulp mill sludge (Aravena et al., 2007; Gallardo et al., 2007 and Gallardo et al., 2012). However, it is important to establish the best sludge-soil dosage in order to minimize the inhibitory effect on mobility of some elements through the soil due to successive applications. 


\subsection{Analysis of $\mathrm{pH}$ in leachates}

The $\mathrm{pH}$ values obtained from leachates after four successive sludge applications ( 0 to $30 \mathrm{Mg} \mathrm{ha}^{-1}$ ) during a year were no different from those of leachates obtained from the control treatment without sludge (Figure 1); no significant differences $(p<0.05)$ between treatments were obtained after the applications. In general, $\mathrm{pH}$ values increased with both the dose and the number of applications, due to the contribution of $\mathrm{Ca}, \mathrm{Na}, \mathrm{Mg}$ and $\mathrm{K}$ present in high concentrations in the sludge used in this study (Table 1). The main increase in $\mathrm{pH}$ was observed after the fourth application at a rate of $30 \mathrm{Mg}$ ha $^{-1}$ sludge with a $\mathrm{pH}$ value close to 6.2 . Nevertheless, these $\mathrm{pH}$ values are within the limit set for irrigation water according to the Chilean Standard NCh 1333. Of 78 ( $\mathrm{pH} 5.5-9.0)$. Therefore the $\mathrm{pH}$ values of the leachates in the soil columns amended with sludge do not constitute an environmental risk. Similar behavior was reported by Santibañez et al. (2007) using sewage sludge for mine tailing re-vegetation.

Table 1. Chemical characteristics of soil (Freire Series) and pulp mill sludge

\begin{tabular}{|c|c|c|c|}
\hline Parameter & Unit & Soil & Sludge \\
\hline $\mathrm{pH}\left(1: 2.5 \mathrm{H}_{2} \mathrm{O}\right)$ & & 5.47 & 6.97 \\
\hline Organic matter & $(\%)$ & 10.0 & 68.0 \\
\hline Nitrogen $\left(\mathrm{N}-\mathrm{NH}_{4}{ }^{+}+\mathrm{N}-\mathrm{NO}_{3}{ }^{-}\right)^{*}$ & $(\mathrm{mg} / \mathrm{kg})$ & 19.2 & 586.2 \\
\hline Phosphorus* & $(\mathrm{mg} / \mathrm{kg})$ & 17.5 & 313.0 \\
\hline Potassium* & $(\mathrm{mg} / \mathrm{kg})$ & 355 & 1,251 \\
\hline Sodium* & $(\mathrm{cmol}+/ \mathrm{kg})$ & 0.30 & 41.55 \\
\hline Calcium* & $(\mathrm{cmol}+/ \mathrm{kg})$ & 5.05 & 27.95 \\
\hline Magnesium* & $(\mathrm{cmol}+/ \mathrm{kg})$ & 0.92 & 13.68 \\
\hline Potassium* & $(\mathrm{cmol}+/ \mathrm{kg})$ & 0.89 & 3.62 \\
\hline Aluminum* & $(\mathrm{cmol}+/ \mathrm{kg})$ & 0.07 & 0.03 \\
\hline CEC & $(\mathrm{cmol}+/ \mathrm{kg})$ & 7.16 & 86.80 \\
\hline Aluminum saturation & $(\%)$ & 0.78 & 0.035 \\
\hline Cupper * & $(\mathrm{mg} / \mathrm{kg})$ & 3.2 & 5.04 \\
\hline Manganese* & $(\mathrm{mg} / \mathrm{kg})$ & 6.40 & 111.1 \\
\hline Zinc* & $(\mathrm{mg} / \mathrm{kg})$ & 0.50 & 376.3 \\
\hline Iron* & $(\mathrm{mg} / \mathrm{kg})$ & 54.50 & 18.4 \\
\hline
\end{tabular}

$\mathrm{CEC}=$ Cation exchange capacity $\left(\sum \mathrm{Ca}, \mathrm{Mg}, \mathrm{K}, \mathrm{Na}\right)$

Aluminum saturation $(\%)=\left[\mathrm{Al} /\left(\sum \mathrm{Ca}, \mathrm{Mg}, \mathrm{K}, \mathrm{Na}\right.\right.$ and $\left.\left.\mathrm{Al}\right) * 100\right]$

* Available elements

Values for sludge and soil are in base to dry weight

Values are the average of three replicates $(n=3)$. 


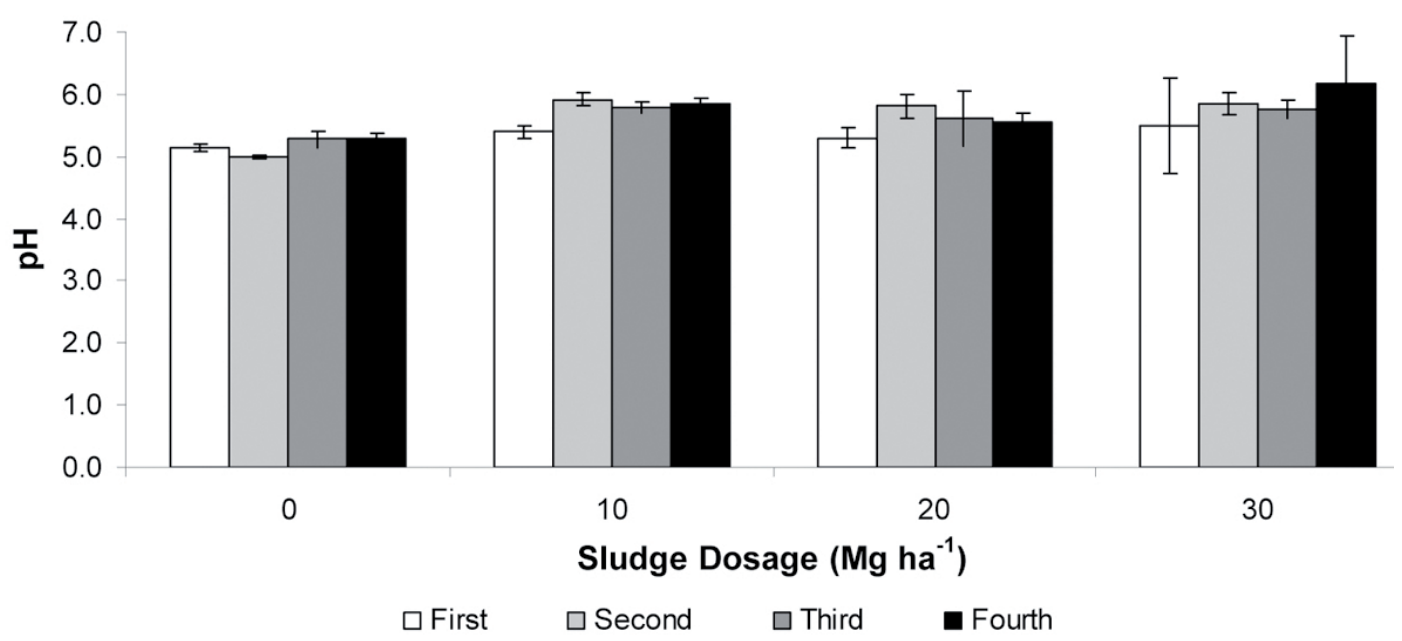

Figure 1. $\mathrm{pH}$ values of leachates collected after four applications of sludge ( 0 to $\left.30 \mathrm{Mg} \mathrm{ha}^{-1}\right)$ during a year. Bars indicate standard error of the mean $(n=3)$.

3.3. Analysis of nitrate, ammonium and phosphorus in leachates

The descent of water through soil can result in leaching of $\mathrm{N}$, usually in the form of $\mathrm{NO}_{3}^{-}-\mathrm{N}$. This can have adverse effects on the environment, such as groundwater contamination. However, the use of organic residues in agriculture, with appropriate management, can help to lower $\mathrm{NO}_{3}^{-}-\mathrm{N}$ leaching as compared with application of $\mathrm{N}$ in mineral form (Carneiro et al., 2012). We evaluated the effect of successive applications of pulp mill sludge to soil on $\mathrm{NO}_{3}^{-}$-N leaching after one year of treatment. The results are shown in Figure 2. In general, the $\mathrm{NO}_{3}^{-}-\mathrm{N}$ content rose with the increase of both the dose and the number of applications. There was no significant difference $(p<0.05)$ in $\mathrm{NO}_{3}^{-}-\mathrm{N}$ content between treatments for the first application of sludge, with average of about
$15 \mathrm{mg} \mathrm{L}^{-1}$ of $\mathrm{NO}_{3}^{-}-\mathrm{N}$ in the leachates. However, the $\mathrm{NO}_{3}^{-}-\mathrm{N}$ concentration gradually increased from 15 to $26 \mathrm{mg} \mathrm{L}^{-1}$ when higher levels of sludge application were used and after the fourth application. According to FAO guidelines, a concentration between $5 \mathrm{mg} \mathrm{L}^{-1}$ and $30 \mathrm{mg} \mathrm{L}^{-1} \mathrm{NO}_{3}^{-}-\mathrm{N}$ is permitted for irrigation water; this means that a fourth application of sludge at a rate of $30 \mathrm{Mg} \mathrm{ha}^{-1}$ could represent some risk whenever the $\mathrm{NO}_{3}^{-}-\mathrm{N}$ concentration in the leachate approaches the upper limit. The $\mathrm{NO}_{3}^{-}$-Nis readily dissolved in soil water, therefore it will move with water. The high available $\mathrm{N}$ content in sludge (586 $\mathrm{mg} \mathrm{kg}^{-1}$ ), the high irrigation rate applied to the columns, and the negative charge of $\mathrm{NO}_{3}^{-}-\mathrm{N}$ (preventing its adsorption on soil adsorption sites), are all factors that could contribute to $\mathrm{NO}_{3}^{-}-\mathrm{N}$ leaching after the addition of sludge to soil. Although the level of $\mathrm{NH}_{4}^{+}-\mathrm{N}$ in the leachates of the various treatments presented significant differences 
$(p<0.05)$, it was low in all treatments $\left(<1.8 \mathrm{mg} \mathrm{L}^{-1}\right)$ (Figure 3). When sludge was added at rate of $10 \mathrm{Mg}$ ha ${ }^{-1}$, the concentration of $\mathrm{NH}_{4}^{+}-\mathrm{N}$ was the highest after the first application, whereas no differences were observed after the second, third and fourth applications. When sludge was added at rate of $20 \mathrm{Mg}$ ha- ${ }^{-1}$ however, a high $\mathrm{NH}_{4}^{+}-\mathrm{N}$ concentration in leachate was observed after the second application $\left(1.6 \mathrm{mg} \mathrm{L}^{-1}\right)$; the values for $\mathrm{NH}_{4}^{+}-\mathrm{N}$ decreased to approx. $0.9 \mathrm{mg} \mathrm{L}^{-1}$ after the third and fourth applications. When sludge was added at rate of $30 \mathrm{Mg} \mathrm{ha}^{-1}$, the concentration of $\mathrm{NH}_{4}{ }^{+} \mathrm{N}$ was higher after the first, second and fourth applications than the third application. The variations in $\mathrm{NH}_{4}^{+}-\mathrm{N}$ values in leachates are associated with the nitrification process, as we can confirm by the increase of $\mathrm{NO}_{3}^{-}-\mathrm{N}$ in the leachates (Figure 2). Similar results have been obtained by other researchers who have investigated the effect on $\mathrm{N}$ of repeated applications of sludge (Burton et al., 1990; Egiarte et al., 2005; Santibañez et al., 2007). In our study, the highest $\mathrm{NH}_{4}^{+}-\mathrm{N}$ concentrations $\left(1.7 \mathrm{mg} \mathrm{L}^{-1}\right)$ were observed for the treatments that received $20 \mathrm{Mg}$ $\mathrm{ha}^{-1}$ and $30 \mathrm{Mg}$ ha ${ }^{-1}$ sludge. Finally, in the control column (without sludge), the $\mathrm{NH}_{4}^{+}-\mathrm{N}$ concentration diminished strongly from 0.9 to $0.1 \mathrm{mg} \mathrm{L}^{-1}$, due to nitrification resulting from the high biological activity generally detected in Andisols, and the high irrigation rate (1200 $\mathrm{mm}$ per year). Nitrogen mineralization and nitrification increased with irrigation.

The presence of $\mathrm{P}$ in the leachates was also analyzed; however it was not detected after four sludge applications at dosage of 0 to $30 \mathrm{Mg} \mathrm{ha}^{-1}$ over one year of treatment. The $\mathrm{P}$ is extremely immobile in soils, especially those with acidic $\mathrm{pH}$ such as Andisols where the bulk of $\mathrm{P}$ accumulates as macromolecular-P complexes closely associated with OM, possibly through $\mathrm{Al}$ and Fe bridges (Redel et al., 2007).

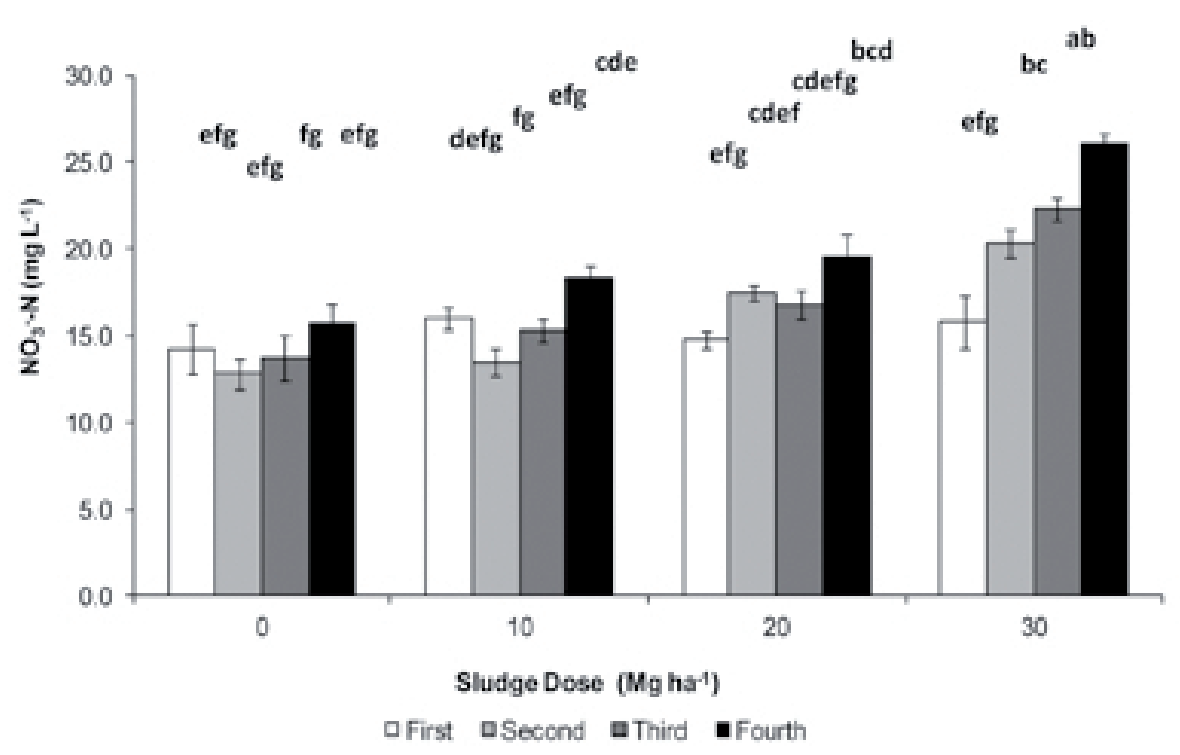

Figure 2. Nitrate $\left(\mathrm{NO}_{3}^{-}-\mathrm{N}\right)$ concentration in leachates collected after four applications of sludge ( 0 to $\left.30 \mathrm{Mg} \mathrm{ha}^{-1}\right)$ during a year. Bars indicate standard error of the mean $(n=3)$. Means with different letters differ significantly by Tukey test $(p<0.05)$. 


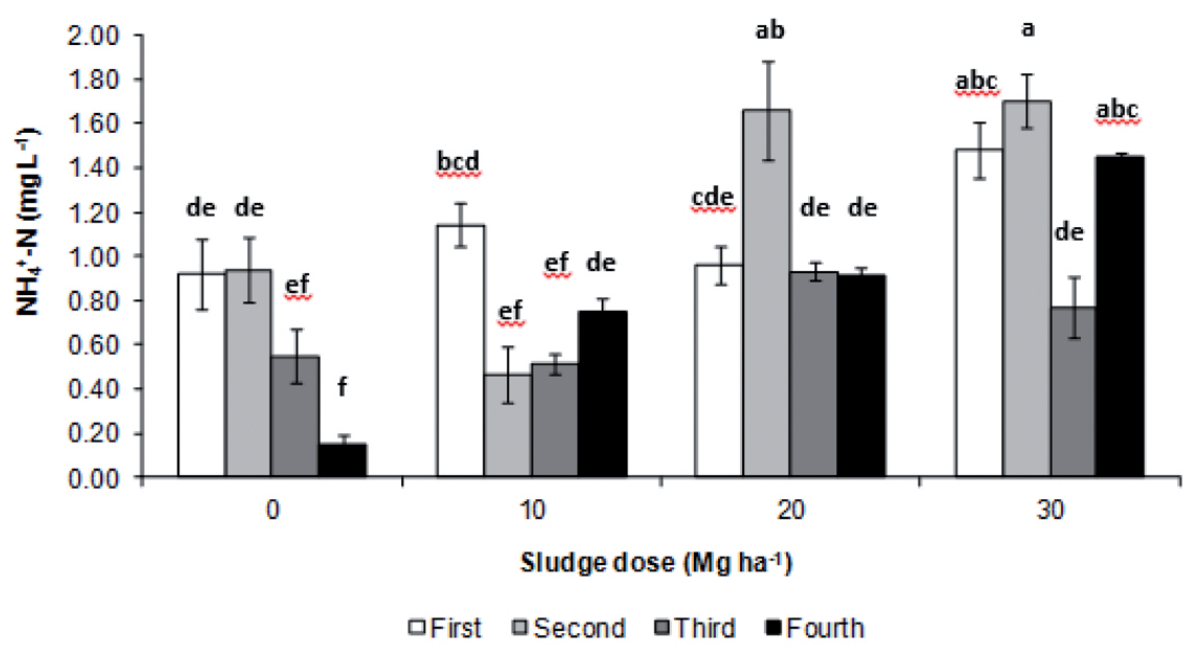

Figure 3. Ammonium $\left(\mathrm{NH}_{4}{ }^{+} \mathrm{N}\right)$ concentration in leachates collected after four applications of sludge (0 to $30 \mathrm{Mg}$ $\left.\mathrm{ha}^{-1}\right)$ during a year. Bars indicate standard error of the mean $(\mathrm{n}=3)$. Means with different letters differ significantly by Tukey test $(p<0.05)$.

\subsection{Analyses of soil in fractionated columns}

The positive effect of the application of pulp mill sludge to soils increases with the amount of sludge applied (Gallardo et al., 2007, Nunes et al., 2008; Ribeiro et al., 2010; Gallardo et al, 2012). However, to ensure that repeated sludge applications are managed sustainably, the cumulative effect of nutrients and contaminants on the soil must be taken into account. In this study, we used an Andisol characterized by high $\mathrm{P}$ adsorption capacity, low base saturation percentage, high levels of exchangeable Al, and moderate acidity (Gallardo et al., 1999; Mora et al., 2004). The $\mathrm{P}$ in these soils is usually stored in a non-available form for plants, and $\mathrm{P}$ fertilization is required to obtain a higher crop yield (Mora et al., 2004). Taking into account the characteristics of the sludge (rich in OM, N and P), it could be an appropriate option for improving the soil characteristics and productivity of Andisols while reducing the use of inorganic fertilizers.
Values of $\mathrm{pH}, \mathrm{OM}$, total $\mathrm{N}$ and available $\mathrm{P}$ in the fractionated soil columns after four successive applications of sludge to soil during one year are shown in Table 2 . The soil $\mathrm{pH}$ increased significantly $(p<0.05)$ as the depth in the soil column increased from 0 to $60 \mathrm{~cm}$. The average $\mathrm{pH}$ values were 5.26 , 5.52 and 5.72 at $0-20,20-40$ and $40-60 \mathrm{~cm}$ depth respectively. Significant differences $(p<0.05)$ were observed with the increasing dose of sludge at depth $0-20 \mathrm{~cm}$; however, no significant differences $(p<0.05)$ were observed due to the increasing sludge dose applied at depths of 20-40 and 40-60 cm. In general, the use of inorganic $\mathrm{NH}_{4}^{+}-\mathrm{N}$ fertilizers increases acidification in Chilean Andisols, due to nitrification by free $\mathrm{H}^{+}$release (Mora et al., 2004, Mora et al., 2007). In our study, Freire soil was not acidified after four successive applications of sludge. On the contrary, a slight increase in $\mathrm{pH}$ was observed in the upper soil fractions; the production of $\mathrm{H}^{+}$through 
nitrification was probably compensated by the large amounts of bases added with the sludge, almost ten times higher than in soil (Table 1).

The OM content was highest at the top of the columns, decreasing as the column depth increased. However, an increment of OM content in the first fraction of the soil columns $(0-20 \mathrm{~cm})$ was observed as the sludge application increased, and significant differences $(p<0.05)$ were found between the control (without sludge) and the highest sludge dose applied (30 Mg ha ${ }^{-1}$ ). Soil analysis in the 20-40 and 40-60 $\mathrm{cm}$ fractions showed no significant differences when different doses of sludge were applied compared with the control at each depth. The OM content changed from $12.46 \%$ average at $0-20 \mathrm{~cm}$ depth to $3.24 \%$ average at $40-60 \mathrm{~cm}$ depth.

Table 2. Organic matter $(\mathrm{OM}), \mathrm{pH}$, total nitrogen $(\mathrm{N})$, available phosphorus $(\mathrm{P})$, nitrate $\left(\mathrm{NO}_{3}^{-}-\mathrm{N}\right)$ and ammonium $\left(\mathrm{NH}_{4}{ }^{+} \mathrm{-N}\right)$ concentrations in fractionated soil columns $(0-20,20-40$ and $40-60 \mathrm{~cm}$ depth) with pulp mill sludge $(0$ to $30 \mathrm{Mg} \mathrm{ha}^{-1}$ ) after a year of leaching experiment.

\begin{tabular}{|c|c|c|c|c|c|c|c|}
\hline Sludge & $\begin{array}{l}\text { Soil } \\
\text { depth }\end{array}$ & $\mathrm{pH}$ & OM & $\mathbf{N}$ & $\mathbf{P}$ & $\mathrm{NO}_{3}^{-}-\mathrm{N}$ & $\mathrm{NH}_{4}{ }^{+}-\mathrm{N}$ \\
\hline$\left(\mathrm{Mg} \mathrm{ha}^{-1}\right)$ & $(\mathrm{cm})$ & & $(\%)$ & $(\%)$ & $\left(\mathrm{mg} \mathrm{kg}^{-1}\right)$ & $\left(\mathrm{mg} \mathrm{kg}^{-1}\right)$ & $\left(\mathrm{mg} \mathrm{kg}^{-1}\right)$ \\
\hline 0 & $0-20$ & $5.20 \pm 0.01 \mathrm{e}$ & $11.60 \pm 0.10 \mathrm{~b}$ & $0.71 \pm 0.01 \mathrm{a}$ & $17.90 \pm 0.42 \mathrm{c}$ & $70.93 \pm 9.60 \mathrm{e}$ & $7.93 \pm 0.40 \mathrm{~b}$ \\
\hline 10 & & $5.22 \pm 0.01 \mathrm{ef}$ & $12.40 \pm 0.77 \mathrm{ab}$ & $0.73 \pm 0.01 \mathrm{a}$ & $17.60 \pm 0.20 \mathrm{c}$ & $113.17 \pm 27.46 \mathrm{de}$ & $9.15 \pm 0.33 b$ \\
\hline 20 & & $5.27 \pm 0.03$ ef & $12.68 \pm 0.32 \mathrm{ab}$ & $0.72 \pm 0.01 \mathrm{a}$ & $19.74 \pm 0.89 \mathrm{bc}$ & $127.63 \pm 7.19$ bcde & $11.03 \pm 0.45 \mathrm{ab}$ \\
\hline 30 & & $5.37 \pm 0.03 \mathrm{f}$ & $13.15 \pm 0.6 \mathrm{a}$ & $0.80 \pm 0.01 \mathrm{a}$ & $24.62 \pm 1.09 \mathrm{a}$ & $185.00 \pm 20.78 \mathrm{ab}$ & $12.37 \pm 0.47 \mathrm{a}$ \\
\hline 0 & $20-40$ & $5.57 \pm 0.09 \mathrm{abc}$ & $6.33 \pm 0.17 \mathrm{c}$ & $0.43 \pm 0.02 b$ & $1.19 \pm 0.28 \mathrm{~d}$ & $108.97 \pm 23.73 \mathrm{de}$ & $2.03 \pm 0.28 \mathrm{e}$ \\
\hline 10 & & $5.55 \pm 0.06 \mathrm{abcd}$ & $6.91 \pm 0.15 \mathrm{c}$ & $0.39 \pm 0.01 \mathrm{~b}$ & $0.63 \pm 0.21 \mathrm{e}$ & $127.40 \pm 1.40$ bcde & $3.18 \pm 0.42 \mathrm{de}$ \\
\hline 20 & & $5.49 \pm 0.04 \mathrm{bcd}$ & $6.01 \pm 0.09 \mathrm{c}$ & $0.40 \pm 0.01 \mathrm{~b}$ & $0.96 \pm 0.12 \mathrm{~d}$ & $176.20 \pm 18.42 \mathrm{abcd}$ & $4.17 \pm 0.21 \mathrm{~cd}$ \\
\hline 30 & & $5.48 \pm 0.05 \mathrm{~cd}$ & $6.04 \pm 0.16 \mathrm{c}$ & $0.40 \pm 0.02 \mathrm{~b}$ & $0.58 \pm 0.12 \mathrm{e}$ & $235.80 \pm 9.92 \mathrm{bcd}$ & $4.98 \pm 0.30 \mathrm{c}$ \\
\hline 0 & $40-60$ & $5.74 \pm 0.09 \mathrm{ab}$ & $3.37 \pm 0.15 \mathrm{~d}$ & $0.24 \pm 0.01 \mathrm{c}$ & $0.82 \pm 0.40 \mathrm{~d}$ & $118.77 \pm 17.96 \mathrm{cde}$ & $1.01 \pm 0.63 \mathrm{f}$ \\
\hline 10 & & $5.73 \pm 0.02 \mathrm{ab}$ & $3.11 \pm 0.07 \mathrm{~d}$ & $0.23 \pm 0.01 \mathrm{c}$ & $0.72 \pm 0.28 \mathrm{de}$ & $158.67 \pm 14.41 \mathrm{bcd}$ & $1.46 \pm 0.62$ ef \\
\hline 20 & & $5.72 \pm 0.06 \mathrm{ab}$ & $3.23 \pm 0.08 \mathrm{~d}$ & $0.25 \pm 0.01 \mathrm{c}$ & $0.39 \pm 0.04 \mathrm{f}$ & $199.67 \pm 9.26 \mathrm{abc}$ & $2.15 \pm .014 \mathrm{e}$ \\
\hline 30 & & $5.72 \pm 0.03 \mathrm{a}$ & $3.25 \pm 0.04 \mathrm{~d}$ & $0.26 \pm 0.01 \mathrm{c}$ & $0.49 \pm 0.08 \mathrm{f}$ & $264.83 \pm 17.55 \mathrm{a}$ & $2.47 \pm 0.07 \mathrm{e}$ \\
\hline
\end{tabular}

Same letters in the same column indicate no significant difference at $p<0.05$.

Values are mean \pm standard error of the mean $(n=3)$. 
A similar tendency was found for total nitrogen values in sludge-amended soil columns.

The highest values of $\mathrm{N}$ were found at the top of the columns and the lowest values at the bottom. Total $\mathrm{N}$ in fractionated soil columns was not modified significantly by the addition of sludge. At $0-20 \mathrm{~cm}$ depth the total $\mathrm{N}$ concentration was in the range of 0.7 to $0.8 \%$ when sludge was applied at a rate of 0 to $30 \mathrm{Mg} \mathrm{ha}^{-1}$, whereas the total $\mathrm{N}$ concentrations at 20-40 and 40-60 cm depth were about $0.4 \%$ and $0.24 \%$ respectively.

The $\mathrm{N}$ content in the $0-20 \mathrm{~cm}$ fraction increased from 17.60 to $24.60 \mathrm{mg} \mathrm{kg}^{-1}$ with the different sludge doses (addition of sludge at 10 to $30 \mathrm{Mg} \mathrm{ha}^{-1}$ respectively). The concentration of $\mathrm{P}$ was more than 20 times higher in the upper part of the soil column and the addition of sludge did not influence the $\mathrm{P}$ content below $20 \mathrm{~cm}$ depth. P accumulated markedly in the first $20 \mathrm{~cm}$ of soil,due to the high $\mathrm{P}$ content (313 $\mathrm{mg} \mathrm{kg}^{-1}$ ) in the sludge and the low mobility of this element, especially in acidic soils. The $\mathrm{P}$ accumulation is an important aspect in Andisols, since they have a strong capacity for fixing $\mathrm{P}$ associated with acidic $\mathrm{pH}$ and high $\mathrm{Al}$ saturation percentage (Gallardo et al., 1999). In general, there is an inverse relationship between $\mathrm{pH}$ and Al saturation as well as between $\mathrm{P}$ availability and Al saturation percentage in Andisols (Mora and Demanet, 1999). Small increments in $\mathrm{pH}$ due to the addition of pulp mill sludge to Andisols cause important reductions in the Al saturation percentage (Gallardo et al., 2007). On the other hand, Nunes et al. (2008) reported that the addition of secondary paper mill sludge produced a linear increase in available $\mathrm{P}$ in the soils used in their study. The reduced $\mathrm{P}$ adsorption and increased $\mathrm{P}$ availability following applications of organic residues to soil can be a consequence of several mechanisms: release of inorganic $\mathrm{P}$ from decaying residues, blockage of $\mathrm{P}$ adsorption sites by organic molecules released from the residues, a rise in soil $\mathrm{pH}$ during decomposition and the complexation of soluble $\mathrm{Al}$ and Fe by organic molecules (Haynes and Mokolobate, 2001; Pypers et al., 2005).

The $\mathrm{NO}_{3}^{-}-\mathrm{N}$ content in fractionated soil columns increased with the increasing dose of sludge. The $\mathrm{NO}_{3}^{-}-\mathrm{N}$ content also increased with the soil depth (Table 2). In general, the $\mathrm{NO}_{3}^{-}-\mathrm{N}$ concentration at the highest application of sludge was twice that in the control, and was associated with the level of $\mathrm{NO}_{3}^{-}-\mathrm{N}$ found in leachates (Figure 2). At 0-20 $\mathrm{cm}$ depth, the $\mathrm{NO}_{3}^{-}-\mathrm{N}$ concentration increased from about $70 \mathrm{mg} \mathrm{kg}^{-1}$ (control) to $185 \mathrm{mg} \mathrm{kg}^{-1}$ at a rate of $30 \mathrm{Mg} \mathrm{ha}^{-1}$. At the same rate of sludge application, the increase of $\mathrm{NO}_{3}^{-}-\mathrm{N}$ concentration was from $108 \mathrm{mg} \mathrm{kg}^{-1}$ to $235 \mathrm{mg} \mathrm{kg}^{-1}$ at $20-40 \mathrm{~cm}$ depth, and from $118 \mathrm{mg} \mathrm{kg}^{-1}$ to $264 \mathrm{mg} \mathrm{kg}^{-1}$ at 40 $60 \mathrm{~cm}$ depth. As it is highly water soluble, $\mathrm{NO}_{3}^{-}$ $-\mathrm{N}$ is the most polluting inorganic $\mathrm{N}$ compound. In our study, up to $25 \mathrm{mg} \mathrm{L}^{-1}$ were measured in leachate after application of $30 \mathrm{Mg} \mathrm{ha}^{-1}$ sludge (Figure 2). Consequently, the highest concentration of $\mathrm{NO}_{3}-\mathrm{N}$ was found in the deepest fraction of the soil columns and is associated with the highest sludge dosage (Table 2). The $\mathrm{NO}_{3}^{-}-\mathrm{N}$ was found to have lixiviated from the soil columns due to its high solubility and negative charge, which prevent its adsorption by soil exchange sites; lixiviation was further influenced by the high water regime $(1200 \mathrm{~mm}$ per year) and by the type of soil used (Andisol). A history of previous sludge application has been shown to affect the potential for The $\mathrm{NO}_{3}^{-}-\mathrm{N}$ leaching. Some authors have reported that greater The $\mathrm{NO}_{3}^{-}-\mathrm{N}$ leaching losses have been observed in sites subjected to reapplication of sludge than 
in sites in which no sludge had previously been applied (Burton et al., 1990; Mitchell et al., 2000). The concentration of $\mathrm{NH}_{4}+-\mathrm{N}$ was highest in the upper part of the soil columns and lowest at the bottom, and increased as the sludge application rates rose in each column profile (Table 2). An accumulation of $\mathrm{NH}_{4}^{+}-\mathrm{N}$ was observed in the 0-20 $\mathrm{cm}$ fraction of the soil columns, increasing from $7.9 \mathrm{mg} \mathrm{kg}^{-1}$ in the control column to $12.4 \mathrm{mg} \mathrm{kg}^{-1}$ in the soil column with the addition of sludge at a rate of $30 \mathrm{Mg} \mathrm{ha}^{-1}$. On the other hand, as the soil depth increased, the values for $\mathrm{NH}_{4}^{+}-\mathrm{N}$ also decreased, ranging from $1 \mathrm{mg} \mathrm{kg}^{-1}$ in the control soil columns to $2.47 \mathrm{mg} \mathrm{kg}^{-1}$ in columns with sludge addition at a rate of $30 \mathrm{Mg} \mathrm{ha}^{-1}$.

The fact that the lowest $\mathrm{NH}_{4}^{+}-\mathrm{N}$ concentration is found in the deepest fraction may be explained by the high affinity of this cation for negatively charged surfaces. This has a strong effect in Chilean Andisols, in which the typical zero point charge is around 4.0-4.5 (Mora et al., 2004). This cation is adsorbed on soil colloids by cationic exchange, or on soil organic matter. Besides, the existence of a high population of nitrifiers in soils induced by previous sludge application - promotes the transformation of $\mathrm{NH}_{4}^{+}-\mathrm{N}$ to $\mathrm{NO}_{3}^{-}-\mathrm{N}$. Similar results have been obtained by other researchers who have investigated the effect of repeated sludge applications on $\mathrm{N}$ processes (Burton et al., 1990). The concentrations of $\mathrm{NO}_{3}^{-}-\mathrm{N}$ and $\mathrm{NH}_{4}{ }^{+} \mathrm{N}$ in soil columns in the same fraction followed an inverse pattern (Table 2). Whereas the $\mathrm{NH}_{4}^{+}-\mathrm{N}$ concentration was highest in the 0 to $20 \mathrm{~cm}$ fraction, the $\mathrm{NO}_{3}^{-}-\mathrm{N}$ concentration was lowest at the same depth. Pulp mill sludge addition produced a linear increase in the $\mathrm{NH}_{4}^{+}-\mathrm{N}$ and $\mathrm{NO}_{3}^{-}-\mathrm{N}$ content in fractionated soil columns (Figure $4 \mathrm{a}$ and $\mathrm{b}$ ) at the three depths analyzed. The $\mathrm{NH}_{4}{ }^{+}-\mathrm{N}$ content in the three column profiles was strongly correlated to sludge concentration, with $\mathrm{r}^{2}>0.98$ in all cases. A similar situation was found for the $\mathrm{NO}_{3}^{-}-\mathrm{N}$ content, with $\mathrm{r}^{2}>0.95$ (Figures $4 \mathrm{a}$ and $\mathrm{b}$ ).

\section{Conclusions}

The results of this study indicated that repeated applications of pulp mill sludge to Andisol soil contributes to an increase in $\mathrm{NO}_{3}^{-}-\mathrm{N}$ and $\mathrm{NH}_{4}^{+}-\mathrm{N}$ concentrations in leachates, whereas the $\mathrm{pH}$ and phosphorus in soil column leachates were not affected by the sludge. Pulp mill sludge improved some properties of the Andisol, increasing the $\mathrm{OM}$ and $\mathrm{P}$ concentrations in soil columns slightly as the sludge rate increased, mainly in the upper part of the columns. Sludge increased $\mathrm{NO}_{3}^{-}-\mathrm{N}$ and $\mathrm{NH}_{4}{ }^{+} \mathrm{N}$ contents. However, these two parameters presented inverse patterns across the depth profile: the $\mathrm{NH}_{4}^{+}-\mathrm{N}$ concentration was highest in the 0 to $20 \mathrm{~cm}$ fraction, while the $\mathrm{NO}_{3}^{-}-\mathrm{N}$ concentration was lowest in the same fraction. Sludge addition produced a linear increase in $\mathrm{NH}_{4}^{+}{ }^{+} \mathrm{N}$ and $\mathrm{NO}_{3}{ }^{-}$ $-\mathrm{N}$ content at the three depths analyzed $\left(\mathrm{r}^{2}>0.95\right)$. While sludge addition improved the availability of nutrients in the soil, the risk of $\mathrm{NO}_{3}^{-}-\mathrm{N}$ lixiviation is high if the sludge rate and periodicity is not regulated, and may present some threat to water quality. 

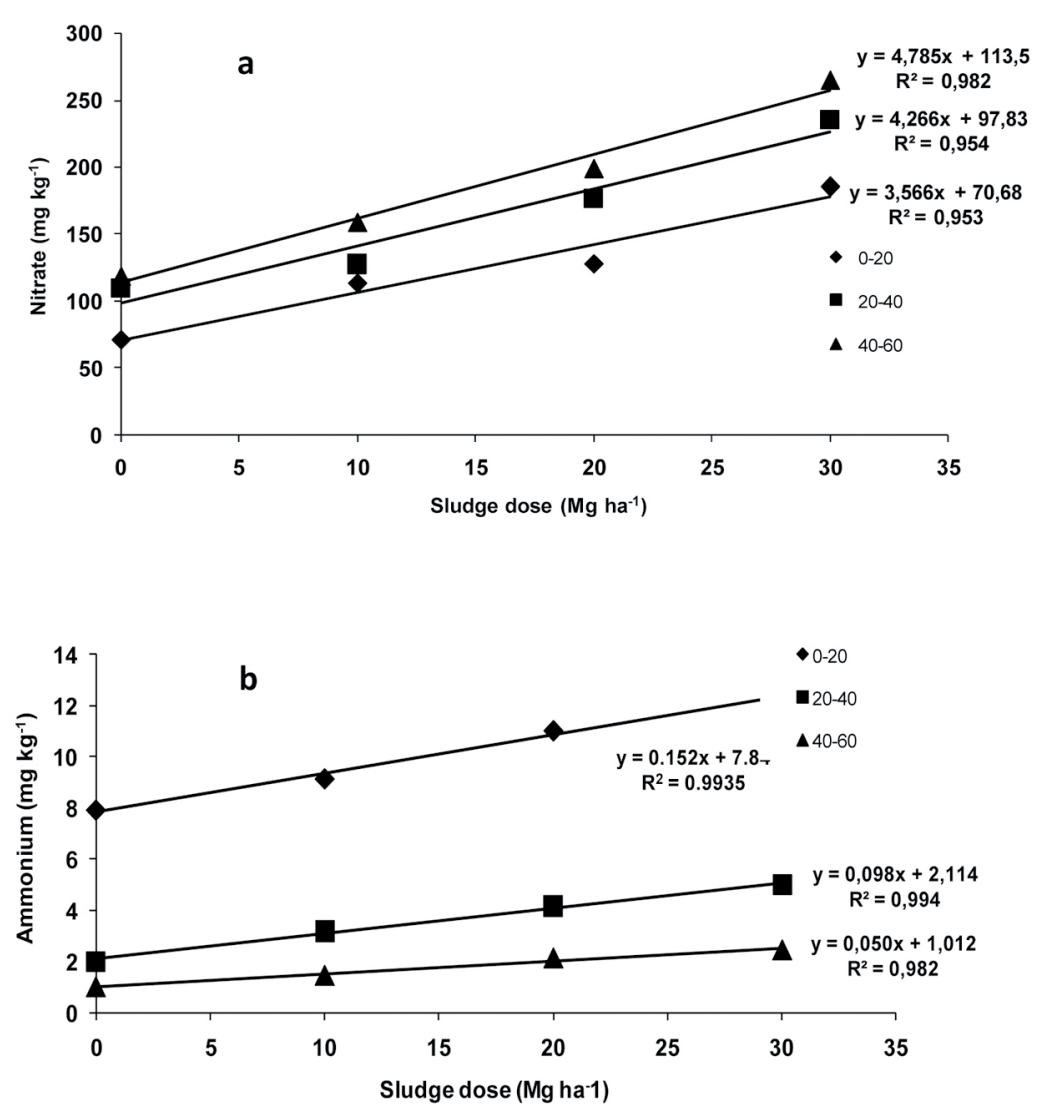

Figure 4. Relation of nitrate $\left(\mathrm{NO}_{3}^{-}-\mathrm{N}\right)$ (a) and ammonium $\left(\mathrm{NH}_{4}^{+}-\mathrm{N}\right)$ (b) content with the soil depth in the fractioned column after sludge application.

\section{Acknowledgement}

This study was supported by DIUFRO DI11-1001, INNOVA-CORFO No 09FCO2-6021 and CONICYT/ FONDAP/15130015 projects.

\section{References}

Abdullah, R., Fauziah, C., Rasidah, W., Abu Bakar, R. Characterization and feasibility assessment of recycled paper mill sludges for land application in relation to the environment. Int. J. Environ.Res. Public Health. 12, 9314-9329. 
Aravena, C., Valentin, C., Diez, M.C., Mora, M.L., Gallardo, F. 2007. Aplicación de lodos de planta de tratamiento de celulosa: efecto en algunas propiedades físicas y químicas de suelos volcánicos. J. Soil Sci. Plant Nutr. 7, 1-14.

Burton, A.J., Hart, J.B., Urie, D.H. 1990. Nitrification in sludge amended Michigan forest soils. J. Environ. Qual. 19, 609-616.

Carneiro, J.P., Coutinho, J., Trindade, H. 2012. Nitrate leaching from a maize $\mathrm{x}$ oats double-cropping forage system fertilized with organic residues under Mediterranean conditions. Agr. Ecosyst. Environ. 160, 29-39.

Egiarte, G., Camps-Arbestain, M., Alonso, A., RuízRomera, E., Pinto, M. 2005. Effect of repeated applications of sewage sludge on the fate of $\mathrm{N}$ in soils under Monterey pine stands. Forest Ecol. Manag. 216, 257-269.

Feldkinchner, D., Wang, C., Gower, S., Kruger, E., Ferris, J. 2003. Effects of nutrient and paper mill biosolids amendment on growth and nutrient status of hardwood forest. Forest Ecol. Manag. 177, 95-116

Gallardo, F., Borie, F., Alvear, M., Von Baer, E. 1999. Evaluation of aluminum tolerance of three barley cultivars by two short-term screening methods and field experiments. J. Soil Sci. Plant Nutr. 45, 413-419.

Gallardo, F., Mora, M.L., Diez, M.C. 2007. Kraft mill sludge to improve vegetal production in Chilean Andisol. Water Sci. Technol. 55, 31-37.

Gallardo, F., Bravo, C., Briceño, G., Diez, M.C. 2010. Use of sludge from kraft mill wastewater treatment as improver of volcanic soils: Effect on soil biological parameters. J. Soil Sci. Plant Nutr. 10, 48-61.
Gallardo, F., Cea, M., Tortella, G.R., Diez, M.C. 2012. Effect of pulp mill sludge on soil characteristics, microbial community and vegetal production of Lolium perenne. J. Environ. Manage. 95, S193-S198.

Gilmour, J.T., Cogger, C.G., Jacobs, L.W., Evanylo, G.K., Sullivan, D.M. 2003. Decomposition and plant available nitrogen in biosolids: laboratory studies, field studies, and computer simulation. J. Environ. Qual. 32, 1498-1507.

Haynes, R.J., Mokolobate, M.S. 2001. Amelioration of Al toxicity and P deficiency in acid soils by additions of organic residues: a critical review of the phenomenon and the mechanisms involved. Nutr. Cycl. Agroecosys. 59, 47-63.

Hossain, K., Ismail, N. 2015. Bioremediation and Detoxification of Pulp and Paper Mill Effluent: A Review. Res. J. Environ. Tox. 9, 113-134.

Instituto Nacional de Normalización (INN). 2004. Norma Chilena de Compost (NCh 2880-2004), Compost -Clasificación y Requisitos, 23 pp.

Masud, M.M., Li, J.Y., Xu, R. K. 2014. Use of alkaline slag and crop residue biochars to promote base saturation and reduce acidity of an acidic Ultisol. Pedosphere. 24, 791-798.

Ministerio de Obras Públicas (1978). Decreto Supremo N ${ }^{\circ} 867$. (INN). Requisitos de calidad del agua para diferentes usos Norma Chilena (NCh 1333-1978).

Mitchell, D.S., Edwards, A.C., Ferrier, R.C. 2000. Changes influxes of $\mathrm{N}$ and $\mathrm{P}$ in water draining a stand of Scots pine treated with sewage sludge. Forest Ecol. Manag.139, 203-213.

Mora, M.L., Demanet, R. 1999. Uso de enmiendas calcáreas en suelos acidificados. Frontera Agricola. 5, 43-58. 
Mora, M.L., Alfaro, M., Williams, P.H., Stehr, W., Demanet, R. 2004. Effect of fertilizer input on soil acidification in relation to growth and chemical composition of a pasture and animal production. J. Soil Sci. Plant Nutr. 4, 29-40.

Mora, M.L., Cartes, P., Núñez, P. Salazar, M., Demanet, R. 2007. Movement of $\mathrm{NO}_{3}^{-}{ }^{-} \mathrm{N}$ and $\mathrm{NH}_{4}+-\mathrm{N}$ in an Andisol and its influence on Ryegrass production in a short term study. J. Soil Sci. Plant Nutr. 7, 46-64.

Nunes, J.M., Cabral F., López, A. 2008 Short-term effects on soil properties and wheat production from secondary paper sludge application on two Mediterranean agricultural soils. Bioresource Technol. 99, 4935-4942.

Pypers, P., Verstraete, S., Thi, C.P., Merckx, R. 2005. Changes in mineral nitrogen, phosphorus availability and salt-extractable aluminium following the application of green manure residues in two weathered soils of South Vietnam. Soil Biol. Biochem. 37, 163-172.

Redel, Y.D., Rubio, R., Rouanet, J.L., Borie, F. 2007. Phosphorus bioavailability affected by tillage and crop rotation on a Chilean volcanic derived Ultisol. Geoderma. 139, 388-396.

Ribeiro, P., Albuquerque, A., Quinta-Nova, L., Cavaleiro, V. 2010. Recycling pulp mill sludge to improve soil fertility using GIS tools. Resour. Conserv. Recy. 54, 1303-1311.
Sadzawka, A., Grez, R., Mora, M.L., Saavedra, N., Carrasco, M.A., Rojas, C. 2004. Métodos de análisis recomendados para suelos chilenos, programa de normalización de técnicas y acreditación de laboratorios para los análisis de suelos y tejidos vegetales. 6-63.

Sánchez, M., Mondini, C., Denobili, M., Leita, L., Roig, A. 2004. Land application of biosolids. Soil response to different stabilization degree or treated organic matter. Waste Manage. 24, 325332 .

Santibañez, C., Ginocchio, R., Varnero, M. 2007. Evaluation of nitrate leaching from mine tailings amended with biosolid under Mediterranean type climate condition. Soil Biol. Biochem. 39, 1333-1340.

Tamir, G., Shenker, M., Heller, H., Bloom, P., Fine, P. and Bar-Tal, A. 2013. Organic N mineralization and transformations in soils treated with animal waste in relation to carbonate dissolution and precipitation. Geoderma. 209-210, 50-56.

Yuan, J. H., Xu, R. K., Wang, N., Li, J. Y. 2011. Amendment of acid soils with crop residues and biochars. Pedosphere. 21, 302-308. 